\title{
Board Independence and Firm Financial Performance: Context of Publicly Traded Manufacturing Companies in Bangladesh
}

\author{
Md. Maniruzzaman \\ Assistant Professor \\ Department of Accounting and Information Systems, University of Rajshahi \\ PO box 6205, Rajshahi, Bangladesh \\ Syed Zabid Hossain \\ Professor \\ Department of Accounting and Information Systems, University of Rajshahi \\ PO box 6205, Rajshahi, Bangladesh
}

\begin{abstract}
This study strives to investigate the effects of board independence on financial performance of publicly held manufacturing companies in Bangladesh using both accounting (ROA) and market-based (Tobin's Q) performance measures. Initially, we select 150 manufacturing companies but only 85 companies remain in the study sample after fulfilling the data availability criteria over a period from 2006-2017. The OLS regression model reveals that board independence has positive effects on both ROA and Tobin's Q, which supports some prior studies (Pearce\& Zahra, 1991; Zahra \& Pearce, 1989; Ezzamel\&Watson, 1993; Hossain, Prevost \&Roa, 2001; Choi, Park \&Yoo, 2007; Joh\& Jung, 2012), but the relationship between board independence and Tobin's Q are not statistically significant. Bangladesh Securities and Exchange Commission (BSEC) has made it a mandatory requirement in the corporate governance guidelines to include $1 / 5$ th of the total directors as independent directors into corporate boards for bringing transparency and accountability of its affairs without considering the underlying institutional differences. Though board independence is considered as an important mechanism of corporate board practices in most of the developed economies, it is still less appealing in emerging economies, especially in Bangladesh.
\end{abstract}

Keywords: Independent directors; firm performance; effective function.

DOI: $10.7176 / \mathrm{EJBM} / 11-33-11$

Publication date: November $30^{\text {th }} 2019$

\section{Introduction}

Following the collapse of some giant corporate entities around the world, most of the companies realize the pivotal roles played by the independent directors as their presence add extra monitoring ability on the corporate board which creates a barrier against the self-interest behavior of the agents (Shleifer\&Vishny, 1997).But, an independent director "... should be independent of management and free from anybusiness or other relationship which could materially interfere with the exercise of their independent judgment, apart from their fees and shareholding (The Cadbury Report (992, Code 2.2)." The Cadbury Report in 1992 and the Tyson Report in 2003 discuss in detail the role and duties of an independent director and both the reports mentioned that the presence of independent directors into the corporate board ensures diversity in knowledge and culture which indeed excels the effectiveness of the corporate board. In the corporate world, the board independence is the most important governance variable as it ensures transparency and accountability (Hasanet.al., 2014a). Independent directors can put forward their impartial outlook and actively take part in board discussion and decision-making process. They are supposed to speak for the interest of shareholders especially minority atomistic shareholders and protect their interest. Thus the independent directors should ensure their presence and performance in the board without prejudice and free from any influence of insiders, such as corporate management, executive directors, and the dominant shareholder (if any).

The followers of agency theory believe that there is a sharp contrast exists between principals and agents arising from the separation of ownership and control. Agency theory portrays that an individual tends to show opportunistic behavior rather than altruistic. In line with this thought, the agency theorists assume that agency conflict may happen if the board is controlled by insiders only (see Bathala\& Rao, 1995; Nicholson \& Kiel, 2007; Zahra \&PearceII, 1989). Moreover, a corporate board dominated by insiders may create information asymmetry, and thus lessen the monitoring ability of the board (Solomon, 2007). Dominant insiders may show self-interest behavior to exploit personal benefits at the cost of the organization's economic interests (Deegan, 2006). Hence, agency theorists believe that board having a large number of independent directors may independently observe and guide managers to defend shareholders' interests (Brickley\& Zimmerman, 2010). The division of roles may facilitate boards to carry out their oversight functions more effectively, and thus boards are supposed to be independent (Finkelstein \& Mooney, 2003). Through accentuating the probable difference of interests between shareholders and managers, agency theory anticipates a positive relationship between board independence and 
firm financial performance (Fama, 1980; Scott, 1983; Boyd, 1995). Thus the more the board's independence, the more would be the corporate performance.

In contrast, the main assertion of stewardship theory (Donaldson and Davis, 1991, 1994) is that executive directors are the best stewards of their firm, and thus managerial ownership will add value to the firm. Following this theory, it is argued that directors and/or managers spend their working lives in the company they govern; therefore, they must understand the business (Donaldson and Davis, 1991, 1994). Besides, with their ownership rights, they can make better decisions (Nicholson and Kiel 2007). Thus stewardship theory proposes that independent directors are unnecessary as agents are the best stewards for their organizations and are not influenced by personal goals (Davis et al., 1997; Luan \& Tang, 20`07). Even so, we believe that individuals are opportunistic and self-interested, rather than compassionate, thus there is a need for monitoring by independent directors. Against this backdrop, the present study strives to investigate the effects of board independence on corporate performance to test the theoretical propositions of the agency theory.

The core function of a corporate board is to formulate corporate policy and strategy to accomplish the objectives of the corporate entity. Besides, the board also undertakes controlling functions to observe whether the company is on the right track or not (Zinkin, 2010). Independent directors are appointed considering their knowledge, skill, and aptitude so that they can contribute to the corporate value creation through active and independent participation in the decision making process of the board. Independent directors are supposed to be independent of any control. Corporations appoint independent directors to monitor the performance of executives and top management. Zinkin (2010) mentioned that independent directors should focus on strategy formulation and implementation. Besides, they should ask questions about the businesses that the company ventures in, product market segmentation, and the valuable customers within the market segmentation (Fuzi, Rahim and Tan, 2012). Independent directors having diversified knowledge and expertise in the relevant field would be more willing to challenge the Chief Executive Officers (CEOs) and the management team in board decision making. Board independence ensures good corporate governance, which is a prerequisite for attracting the required capital to ensure continued economic growth and also for maintaining better relations with workers, creditors, and other stakeholders (Hasanet.al., 2014b).

\section{Literature Review}

The concept of board independence has emerged from the context of Anglo-American countries due to scattered ownership pattern of corporations. Thus independent directors' dominated corporate boards have been popular in the United States since the 1960s (Kesner, Victor \& Lamont, 1986). However, researchers have failed to reach a consensus as to whether the presence of independent directors into the corporate boards enhances firm performance. Several empirical studies in the developed economies (Pearce \& Zahra, 1991; Zahra \& Pearce, 1989; Ezzamel\& Watson, 1993; Prevost \&Roa, 2001; Choi, Park\&Yoo, 2007; Joh\& Jung, 2012) have found a positive association between board independence and corporate performance. On the contrary, some previous studies have documented a negative association between board independence and corporate financial performance (Grace, Ireland \& Dunstan, 1995; Baysinger\& Butler,1985; Bhagat\& Black,2002; \& Sharma,1985; Hermalin\&Weisbach, 2003; Rechner\& Dalton,1986; Yermack, 1996). Some empirical studies from emerging economies have also shown a negative association between board independence and corporate financial performance (Rashid, DeZoysa, Lodh\&Rudkin, 2010; Rashid, DeZoysa, Lodh\&Rudkin, 2012). However, some studies have found no significant effect, either positive or negative, of board independence on corporate financial performance (Muth, M. M. and Donaldson, L, 1998).

As the empirical findings of the studies on the association between board independence and corporate financial performance showed a mixed result, Dalton and Daily (1999) defined these findings as "vexing", "contradictory", "mixed" and "inconsistent". The empirical findings suggest that there is logic to opine that the presence of independent directors in the corporate board can ensure good governance or better financial performance. Similarly, there is no predicted relationship between board independence and corporate financial performance using either accounting or market-based measures. The heterogeneous empirical evidence and findings on the relationship between board independence and corporate financial performance may be the outcome of limited methodological procedures or a lack of methodological rigor and model misspecifications in the sense of the omission of variables that affect firm performance (Bathala\& Rao, 1995), differences in institutional factors and managerial behaviors in the market (Fan, Wei \&Xu, 2011). Thus the current study has been undertaken to reinvestigate the impact of board independence on corporate financial performance in a developing country context.

\section{Board independence in the context of Bangladesh}

The main focus of agency theory is to protect and manage shareholders' interests through minimizing agency costs arises from the opportunistic and self-interest behavior of agents. The agency cost could be minimized by including independent directors on the board as they monitor the activities of corporate management (Jenson and Meckling, 1776). This study applies agency theory to justify the relationship between independent directors and corporate 
financial performance. Corporations in Bangladesh are found to be concentrated ownership which poses some difficulties in ensuring board independence as persons appointed as independent directors are either from a company's family-based relationship or as a payback of previous favor (Rashid 2017). Hence most independent directors are friends or friends of friends of the controlling family. It is very difficult to attain board independence in Bangladesh and consequently, the board loses its monitoring power over the actives of management. Thus the relationship between board independence and firm performance may be negative in emerging markets. As boards are not independent enough to control the affairs of management in emerging economies, unacceptable or modified outcomes may be the result. Hence, good performing companies may be reluctant to appoint the required number of independent directors to gain legitimacy. Contrarily, poorly performing companies may tend to enhance the number of independent directors into the board as an effort to improve performance. (Bhagat\& Black, 2002). Besides, most cor[orations in developing countries, particularly in Bangladesh, invest their undiversified human capital in a single firm and they expect some degree of opportunistic and self-interested behavior from their human assets. Hence, board independence may be a balancing force between the board and management (Hillman\&Dalziel, 2003; Kula, 2005; Zahra and PearceI, 1989). The researchers are motivated to investigate the relationship between board independence and firm performance of publicly traded manufacturing companies in the context of Bangladesh. Besides, Bangladesh follows the Anglo-American style of corporate governance, where there is no supervisory board, corporate boards are one-tire in nature in which both inside directors and outside directors work in one organizational layer (Rashid, 2013). The CEO duality remains in many listed companies in Bangladesh. Despite having some similarities in corporate governance practices in Bangladesh with the AngloAmerican countries, say, one-tier board, CEO duality, and common law tradition, most of the firms in Bangladesh are controlled by the family members of the founding family (Maniruzzaman and Hossain, 2019). Similar to other emerging economies, representatives of the family owners hold positions in both the company board and management as opposed to professional managers in Anglo-American countries, leading to poor monitoring and controlling, as well as to incidences of CEO duality in many listed firms in Bangladesh. Such family control is sometimes detrimental to corporate financial performance.

In August 2012, the Bangladesh Securities and Exchange Commission (BSEC), the capital market regulator, made the Corporate Governance Notification (CGN) mandatory with some modifications. Amongst other requirements, publicly traded companies in Bangladesh requires to have at least one-fifth $(1 / 5)$ of the total number of directors shall be independent directors like Anglo- American-style independent directors on their boards. This idea of independent directors work good in the Anglo-American countries, particularly in the United Kingdom, the United States and Canada, as the control of these countries rely deeply on laws and transparency (information disclosure) to enforce shareholders' rights (Asian Development Bank,2000). As opposed to Anglo-American countries, key institutional forces have a very negligible capacity to exercise pressure on corporate management (agent) to discipline them. Rashid (2011) opined that, due to poor enforcement of the law, shareholders right is very poorly protected in Bangladesh; many companies take up to seven years to present their audited financial statements before the Annual General Meeting (AGM) and some even take more than seven years just to disclose the audited financial statements to the outsiders. Uddin and Choudhury (2008) noted that families and their kith and kin sometimes weaken the legal measures, for example, rules and regulations for accountability. In this situation, it is imperative to investigate whether the Western-dominated corporate governance system of board independence can work effectively in an emerging economy.

\section{Hypothesis development}

The rationale behind supporting board independence through the representation of outside directors on boards is that the outsiders can make a positive contribution to the monitoring abilities of boards (Park \& Shin,2004) and thereby, increases corporate financial performance and firm value (see Finkelstein \& Hambrick, 1996; Kesner et al., 1986; Zahra and PearceII,1989 ). In the absence of independent directors, the insider-dominated board can get massive power that it may misuse. Moreover, without the expertise of independent directors, a board may be ineffective (Dalton \&Daily, 1999) and lead to information asymmetry. Agency theorists argue that the most critical board function is to monitor the actions of "agents" (managers) to safeguard the interest of "principals" (shareholders) (see Eisenhardt, 1989; Hillman \&Dalziel, 2003). Under the agency theory, board independence balances the power between insiders and outsiders. Following this rationale, it is argued that board independence augments corporate financial performance.

But, there exist some institutional and behavioral differences between companies in emerging countries and those in developed countries (Fan et al. 2011). As the corporate ownerships are spread out to a large number of shareholders, corporations in developed countries hire highly skilled professional managers, many of them do not have ownership stakes in their companies, whereas in many emerging countries the family owners choose themselves or their close relatives or friends to appoint on corporate boards and management. Anderson and Reeb (2004) argue that families often try to reduce the presence of independent directors as they have a great incentive to consume the resources of their companies. Although many companies appoint independent directors on their 
boards, these directors may not be truly independent. It is not surprising that many of them are friends or friends of friends of the controlling family or inside directors. Thus, board independence is difficult to achieve in some emerging economies and the board cannot exercise effective control over agents (managers). Thus board independence seldom adds any value to corporate entities in emerging markets and a negative relationship quite common between board independence and corporate financial performance. Based on the above discussion, we formulate the following hypothesis:

Hypothesis: Board independence and corporate financial performance are negatively associated with one another.

\section{Methodology}

\subsection{Population and sampling}

Booth et al. (2002) mention that along with a company's internal mechanisms, industry-specific regulations also shape managers' discretion and thus affect corporate financial performance. It is logical to point out that companies with higher regulatory intervention may weaken corporate governance mechanisms, such as banks and financial institutions. Therefore, we limit our sample only to manufacturing companies as it encounters less rigorous industry regulations. We follow the Dhaka Stock Exchange (DSE) industry classification to identify manufacturing companies for the period of 2006-2017. Initially, we take 150 manufacturing companies, but the annual reports are available for 85 companies since the sample is drawn from companies listed on the DSE on or before 2006. The sample size is representative of the population as the market capitalization of 85 sample companies is $69.02 \%$ of the total market capitalization of all the listed manufacturing companies in Bangladesh as of December 31, 2017. Chauhan et al. (2016) conduct a study in India for the period 2003-2013, where they included all the manufacturing companies in India and initially found a total of 970 companies but annual reports were available for 84 companies representing the market capitalization of $55.49 \%$. Rashid (2016) also conducted a study in Bangladesh for the period of 2001-2011 with the sample of all non-financial companies listed on the DSE, but based on the availability of annual reports; his sample includes only 110 companies, resulting in a balanced sample of 1210 observations.

\subsection{Measurement of dependent and independent variables}

The study has adopted two alternative measures to assess corporate performance, one is Return on Assets (ROA) and the other is Tobin's Q. ROA is the backward-looking accounting measure of financial performance and Tobin's $\mathrm{Q}$ is the forward-looking market measure of financial performance (Farooque et al., 2012). However, the capital market in Bangladesh is underdeveloped and highly volatile in nature, and thus market-based measure is not greatly responsive to corporate financial performance. Thus accounting-based measures ROA (return on assets) have been used in this study as it reflects the underlying company's financial performance (Maniruzzaman\& Hossain, 2019). However, the current study uses Tobin's $Q$ as an alternative performance measure of corporate performance. Board independence is the independent variable of the study, which is measured as the ratio of independent directors to the total number of members on the board, which is denoted as BDIND. Besides, the current study uses some control variables, such as firm size, firm age, and industry category. Firm size is the log value of the total assets of the companies and denoted as FZIZE. Firm age refers to the number of years since a company enlisted into the DSE and denoted as FAGE. Food and Allied sector is a reference category that takes a value zero. In Bangladesh, the manufacturing companies are divided into nine different sectors as per the DSE listing, which are Cement, Ceramics, Paper \& Printing, Engineering, Jute, Textile, Pharmaceuticals \& Chemicals, Tannery, and Food \& Allied. Statistical model

To investigate effect of board independence on firm performance, the current study developed the following OLS regression model:

Where,

$$
Y_{i t}=\beta_{0}+\beta_{1} \times \text { BDIND }_{i t}+\beta_{j} \text { Control }_{i t}+\varepsilon_{i t}
$$

$Y_{i t}$ is alternatively $R O A_{i t}$ and Tobin's $Q_{i t}$

$B D I N D_{i t}$ is the board independence for ${ }^{t h}$ firm at time $\mathrm{t}$.

Control $_{i t}$ is the control variables used in the study.

$\beta_{0}$ is the intercept, $\beta 1, \beta 2, \beta 3$, and $\beta 4$ are the regression co-efficient

$\varepsilon_{i t}$ is the error terms

\subsection{Results and Discussion}

Descriptive statistics reveal that the average financial performance of the sample companies as measured by ROA is 8.91 percent ranging from (-) 26 to 56 percent and as measured by Tobin's Q is 106.73 percent ranging from 51 to 152 percent over the period 2006-2017. This situation suggests that for each BDT 100 invested in assets there is a return of BDT 6.73. The average board independence of the sample companies is 1.3943 that reveals on average more than one independent director sits on the corporate board. The average firm size (log value) of the manufacturing companies is 6.9285 ranging from 2.90 to 10.75 . The average log-asset value of each manufacturing company is BDT 6.9285. Similarly, the average log firm age is 2.9131 years. 


\begin{tabular}{|l|r|r|r|r|r|r|}
\hline Table-1 Descriptive Statistics \\
\hline & \multicolumn{1}{|c|}{ ROA } & \multicolumn{1}{l|}{ Tobin's Q } & \multicolumn{1}{l|}{ BDIND } & \multicolumn{1}{l|}{ LEV } & \multicolumn{1}{c|}{ FSIZE } & \multicolumn{1}{l|}{ FAGE } \\
\hline Mean & .0891 & 1.0673 & 1.3943 & .6072 & 6.9285 & 2.9131 \\
\hline Median & .0751 & 1.0552 & 1.0000 & .5498 & 6.9200 & 2.9957 \\
\hline Std. Deviation & .09347 & .11570 & .66433 & .41166 & 1.48003 & .47382 \\
\hline Minimum & -.26 & .51 & 1.00 & .01 & 2.90 & .00 \\
\hline Maximum & .56 & 1.52 & 5.00 & 4.48 & 10.75 & 3.71 \\
\hline
\end{tabular}

To see whether there is any multicollinearity problem associated with variables used in this study, we conducted a Person correlation analysis on the variables in table 2. The results show that ROA and Tobin's Q are positively correlated. Besides, board independence and firm age are also positively correlated with ROA and Tobin's Q but financial leverage is negatively correlated with ROA which in turn positively correlated with Tobin's Q and firm size is positively correlated with ROA but negatively correlated with Tobin's Q. Simple correlation is not harmful unless they exceed 0.80 or 0.90 (Judge et al. (1985); Bryman and Cramer (1997); Hasan et.al., (2014b); Mehedi et.al., 2017. In the interpretation of the results of the multiple regression analysis, the correlation matrix reveals none of the results exceed 0.5 and hence, there is no multicollinearity problem.

\begin{tabular}{|l|r|r|r|r|r|r|}
\hline \multicolumn{1}{|l|}{ Table-2 Correlations coefficient matrix } \\
\hline & \multicolumn{1}{|c|}{ ROA } & \multicolumn{1}{c|}{ Tobin's Q } & \multicolumn{1}{c|}{ BDIND } & \multicolumn{1}{c|}{ LEV } & \multicolumn{1}{c|}{ FSIZE } & FAGE \\
\hline ROA & 1 & & & & & \\
\hline Tobin's Q & $.231^{* *}$ & 1 & & & & \\
\hline BDIND & $.076^{*}$ & .033 & 1 & & & \\
\hline LEV & $-.345^{* *}$ & $.078^{*}$ & .025 & 1 & & \\
\hline FSIZE & $.280^{* *}$ & $-.253^{* *}$ & $.121^{* *}$ & $-.210^{* *}$ & & 1 \\
\hline FAGE & $.180^{* *}$ & $.217^{* *}$ & $.187^{* *}$ & .006 & $.093^{* *}$ & 1 \\
\hline
\end{tabular}

**. Correlation is significant at the 0.01 level (2-tailed).

*. Correlation is significant at the 0.05 level (2-tailed).

It is evident from table- 3 that board independence, firm size, and firm age are positively, and financial leverage is negatively associated with ROA, and the associations are statistically significant. Similarly, board independence, financial leverage, and firm age are positively associated with Tobin's Q, but only the firm age is statistically significant. Contrarily, firm size is negatively associated with Tobin's Q and the association is significant. Contrarily, firm size is negatively associated with Tobin's Q and the association is significant. Independent Directors are appointed on the board to look after the interest of the atomistic minority shareholders and ensure that any deceitful or inept action of corporate management should not go unnoticed. In a perfect world, independent directors should have the independence of mind along with the ability and ethical foundation to judge an issue without prejudice or bias towards the interest of any individual or group of individuals. But in the context of developing economies, especially in Bangladesh, the situation is somewhat different.

In most cases, independent directors usually try to protect the interest of dominant majority shareholders instead of minority shareholders and all other stakeholders. The most revealing feature is that the appointment of independent directors is normally controlled by the dominant majority shareholders. Moreover, it is difficult to find any truly independent person for appointing as an independent director in corporate boards. In such a situation, the BSEC could prepare a panel of deserving candidates having a sound ethical and professional background and make it mandatory to appoint independent directors from that panel following a chronological order. Consequently, board independence and corporate financial performance will increase. There will be a win-win situation both for the minority and majority/ controlling shareholders and good governance will prevail in Bangladesh corporate sector.

On the other hand, control variables such as firm size and firm age are positively associated with ROA and the results are statistically significant. One possible explanation is that the older firm and the larger the size, the higher the firm performance (Dey et al., 2018) However, firm size is negatively and firm age is positively associated with Tobin's Q and in both the cases the results are statistically significant. Another revealing feature is that all the sectors under manufacturing category are negatively associated with ROA and the results are statistically significant. Similarly, all sectors are negatively associated with Tobin's Q except cement sector and the results are statistically significant in case of Ceramics, Paper, Engineering, Jute and Textile sectors but in case of Cement, Pharmaceuticals and Tannery sectors, the regression results are not statistically significant. 
Table 3. Regression results

\begin{tabular}{|c|c|c|c|c|c|c|c|c|}
\hline Variables & \multicolumn{3}{|c|}{ ROA } & \multicolumn{3}{|c|}{ Tobin's Q } & \multicolumn{2}{|c|}{ Collinearity Statistics } \\
\hline & Beta & $\mathbf{T}$ & Sig. & Beta & $\mathbf{T}$ & Sig. & Tolerance & VIF \\
\hline (Constant) & & -4.119 & .000 & & 30.986 & .000 & & \\
\hline BDIND & .097 & 2.664 & .008 & .038 & 1.079 & .281 & .735 & 1.360 \\
\hline LEV & -.075 & -2.150 & .032 & .053 & 1.570 & .117 & .798 & 1.252 \\
\hline FSIZE & .258 & 7.094 & .000 & -.436 & -12.305 & .000 & .729 & 1.372 \\
\hline FAGE & .262 & 7.145 & .000 & .173 & 4.824 & .000 & .716 & 1.397 \\
\hline Cement & -.227 & -5.496 & .000 & .074 & 1.831 & .067 & .567 & 1.765 \\
\hline Ceramics & -.265 & -7.427 & .000 & -.101 & -2.904 & .004 & .757 & 1.321 \\
\hline Paper & -.103 & -3.218 & .001 & -.039 & -1.249 & .212 & .936 & 1.068 \\
\hline Engineering & -.353 & -7.881 & .000 & -.075 & -1.717 & .086 & .481 & 2.079 \\
\hline Jute & -.234 & -6.503 & .000 & -.147 & -4.199 & .000 & .745 & 1.342 \\
\hline Textile & -.473 & -9.430 & .000 & -.154 & -3.151 & .002 & .384 & 2.605 \\
\hline Pharmaceuticals & -.246 & -5.198 & .000 & .082 & 1.777 & .076 & .432 & 2.313 \\
\hline Tannery & -.194 & -5.198 & .000 & -.032 & -.882 & .378 & .696 & 1.438 \\
\hline \multicolumn{4}{|c|}{ Dependent variable: $R O A$} & \multicolumn{5}{|c|}{ Dependent Variable: Tobin's $Q$} \\
\hline \multicolumn{2}{|c|}{ F statistics } & \multicolumn{2}{|c|}{14.216} & \multicolumn{5}{|c|}{16.627} \\
\hline \multicolumn{2}{|l|}{ Significance } & \multicolumn{2}{|c|}{$.000^{\mathrm{b}}$} & \multirow{2}{*}{\multicolumn{5}{|c|}{$.000^{\mathrm{b}}$}} \\
\hline \multicolumn{2}{|l|}{ R Square } & \multicolumn{2}{|c|}{.316} & & & & \multicolumn{2}{|c|}{.350} \\
\hline
\end{tabular}

*Food and Allied sector is a reference category, which takes a value zero. The manufacturing companies in Bangladesh are categorized into nine different sectors as per the Dhaka Stock Exchange, which are Cement, Ceramics, Paper, Engineering, Jute, Textile, Pharmaceuticals, Tannery and Food and Allied.

\section{Conclusion}

We investigate whether board independence has any effect on corporate financial performance in the context of Bangladesh. The OLS regression results show that board independence and corporate financial performance are positively associated with each other, which support the findings of some prior studies (Pearce\& Zahra, 1991; Zahra\&Pearce, 1989; Ezzamel\&Watson, 1993; Hossain, Prevost \&Roa, 2001; Choi, Park \&Yoo, 2007; Joh\& Jung, 2012), and the propositions of agency theory. Besides, this finding does not support the assumptions of the stewardship theory. However, this finding is contrasting with some other previous studies (Rashid, DeZoysa, Lodh\&Rudkin, 2010; Rashid, DeZoysa, Lodh\&Rudkin, 2012) as they found that board independence is not positively associated with firm performance. The main focus of agency theory is to protect the interest of shareholders through minimizing agency cost arising from the opportunistic and self-interested behavior of the agents which could be reduced by appointing independent directors who will act as a monitor over the activities of the management (Jenson and Meckling, 1776). The role of independent directors in the corporate boards in most of the manufacturing companies in Bangladesh adds value similar to the Anglo-American countries, though the ownership pattern in Bangladesh is concentrated to a few hands as opposed to the many developed countries.

\section{Limitation}

This study has several possible limitations. First, the performance measures used in this study may be problematic because accounting standards and their enforcement are very poor in developing countries. Thus, annual reports may not be a true representation of a company's state of affairs and performance. Moreover, it is argued that accounting profits are subject to manipulation (see Healy, 1985; Chakravarthy, 1986; Capon, Farley\&Hoenig, 1996, p89). Similarly, the market performance measure (Tobin's Q) used in this study may be problematic. To apply the stock market performance of the firm, its stock prices must reflect the firm's true value (Lindenberg\& Ross, 1981). Market-based performance measures are also criticized because they may not be 'efficient contracting parameters' or be "driven by many factors beyond the control of firm executives" (Bacidore, Boquist, Milbourn\&Thakor, 1997, p11). Bangladesh is not exception to this. The Bangladeshi stock market underwent major turmoil in 1996 and 2011 that led to market collapse, even though the market was outperforming the markets of many developed economies before it collapsed (see Rashid, 2011). Secondly, the accounting data were collected from a large number of observations of different corporate entities while ignoring the underlying differences in organizations (Deegan, 2006). Finally, the extreme values of some observed variables, such as EBIT and the accumulated profits of a few firms for certain years, may severely impact the outcome of this study. Noting the study limitations outlined above, future studies that examine the relationship between board independence and agency cost or firm efficiency should be carried out. Agency cost or firm efficiency can be measured as:(a) the expense ratio(ER)and(b)the asset utilization ratio(AUR) or assets turnover ratio, also known as agency cost (see Angetal., 2000; Rashid \&Hoque,2011; Rashid, 2013; Singh and Davidson, (2003). 


\section{References}

Anderson, R. C., \&Reeb, D. M. (2004). Board composition: Balancing family influence in S\&P 500 firms. Administrative science quarterly, 49(2), 209-237.

Ang, J. S., Cole, R. A., \& Lin, J. W. (2000). Agency costs and ownership structure. the Journal of Finance, 55(1), 81-106.

Bacidore, J. M., Boquist, J. A., Milbourn, T. T., \&Thakor, A. V. (1997). The search for the best financial performance measure. Financial Analysts Journal, 53(3), 11-20.

Bathala, C. T., \& Rao, R. P. (1995). The determinants of board composition: An agency theory perspective. Managerial and decision economics, 16(1), 59-69.

Baysinger, B. D., \& Butler, H. N. (1985). Corporate governance and the board of directors: Performance effects of changes in board composition. Journal of Law, Economics, \& Organization, 1(1), 101-124.

Bhagat, S., \& Black, B. (2001). The non-correlation between board independence and long-term firm performance. J. CorP. l., 27, 231.

Brennan, N. M., Solomon, J., Uddin, S., \& Choudhury, J. (2008). Rationality, traditionalism and the state of corporate governance mechanisms. Accounting, Auditing \& Accountability Journal.

Brickley, J. A., \& Zimmerman, J. L. (2010). Corporate governance myths: comments on Armstrong, Guay, and Weber. Journal of Accounting and Economics, 50(2-3), 235-245.

Bryman, A., \& Cramer, D. (1997). Quantitative data analysis with SPSS for Windows: A guide for social scientists. Routledge.

Boyd, B. K. (1995). CEO duality and firm performance: A contingency model. Strategic Management Journal, 16(4), 301-312.

Chaganti, R. S., Mahajan, V., \& Sharma, S. (1985). Corporate board size, composition and corporate failures in retailing industry [1]. Journal of management studies, 22(4), 400-417.

Chakravarthy, B. S. (1986). Measuring strategic performance. Strategic management journal, 7(5), 437-458.

Choi, J. J., Park, S. W., \&Yoo, S. S. (2007). The value of outside directors: Evidence from corporate governance reform in Korea. Journal of financial and Quantitative Analysis, 42(4), 941-962.

Chowdhury, S.K., Bhadra, H.K., Maniruzzaman, M. and Mehedi, S. (2017), "Current status and future Projection of food security and nutrition in South Asia: A comparative study", International Journal of Development and Sustainability, Vol. 6 No. 3, pp. 33-53.

Dalton, D. R., \& Daily, C. M. (1999). What's wrong with having friends on the board?.Across the board, 36(3), 28-32.

Davis, J.H.,Schoorman,F.D.,\&Donaldson,L.(1997).Towards a stewardship theory of management. Academy of Management Review, 22(1), 20-47.

Deegan, C.(2006). Financial accounting theory ((Second ed.).Sydney: McGrawHill Australia Pty Ltd.

Donaldson, L., \& Davis, J. H. (1991). Stewardship theory or agency theory: CEO governance and shareholder returns. Australian Journal of management, 16(1), 49-64.

Eisenhardt, K. M. (1989). Agency theory: An assessment and review. Academy of management review, 14(1), 5774.

Ezzamel, M., \& Watson, R. (1993). Organizational Form, Ownership Structure and Corporate Performance: A Contextual Empirical Analysis of UK Companies 1. British Journal of Management, 4(3), 161-176.

Fama, E. F. (1980). Agency problems and the theory of the firm. Journal of political economy, 88(2), 288-307.

Fan, J. P., Wei, K. J., \&Xu, X. (2011). Corporate finance and governance in emerging markets: A selective review and an agenda for future research.

Farooque, O. A., van Zijl, T., Dunstan, K., \& Karim, A. W. (2007). Ownership structure and corporate performance: Evidence from Bangladesh. Asia-Pacific Journal of Accounting \& Economics, 14(2), 127-149.

Finkelstein, S., Hambrick, D., \&Cannella, A. A. (1996). Strategic leadership. St. Paul: West Educational Publishing.

Finkelstein, S., \& Mooney, A. C. (2003). Not the usual suspects: How to use board process to make boards better. Academy of Management Perspectives, 17(2), 101-113.

Grace, M., Ireland, A., \& Dunstan, K. (1995). Board composition, non-executive directors' characteristics and corporate financial performance. Asia-Pacific Journal of Accounting, 2(1), 121-137.

Hasan, M. S., Rahman, R. A., \& Hossain, S. Z. (2014a). Monitoring family performance: family ownership and corporate governance structure in Bangladesh. Procedia-Social and Behavioral Sciences, 145, 103-109.

Hasan, M. S., Hossain, S. Z., \& Rahman, R. A. (2014b). Corporate Governance and corporate accruals: The situation in Bangladesh. Aestimatio, (9), 90.

Healy, P. M. (1985). The effect of bonus schemes on accounting decisions. Journal of accounting and economics, 7(1-3), 85-107.

Hermalin, B. E., \&Weisbach, M. S. (2001). Boards of directors as an endogenously determined institution: A survey of the economic literature (No. w8161). National Bureau of Economic Research. 
Hillman, A. J., \&Dalziel, T. (2003). Boards of directors and firm performance: Integrating agency and resource dependence perspectives. Academy of Management review, 28(3), 383-396.

Jensen, M. C., \&Meckling, W. H. (1976). Theory of the firm: Managerial behavior, agency costs and ownership structure. Journal of financial economics, 3(4), 305-360.

Joh, S. W., \& Jung, J. Y. (2012). The effects of outside board on firm value in the emerging market from the perspective of information transaction costs. Asia-Pacific Journal of Financial Studies, 41(2), 175-193.

Judge, G. G. (1985). The theory and practice of economics. John Willey.

Kesner, I. F., Victor, B., \& Lamont, B. T. (1986). Board composition and the commission of illegal acts: An investigation of Fortune 500 companies. Academy of Management Journal, 29(4), 789-799.

Lindenberg, E. B., \& Ross, S. A. (1981). Tobin's q ratio and industrial organization. Journal of business, 1-32.

Luan, C. J., \& Tang, M. J. (2007). Where is independent director efficacy?.Corporate Governance: An International Review, 15(4), 636-643.

Maniruzzaman.M.,\& Hossain, S. Z., (2019). Corporate Board Attributes and Firm Performance of Publicly Traded Manufacturing Companies in Bangladesh. Research Journal of Finance and Accounting, 10(16), 98-107.DOI: 10.7176/RJFA/10-16-12.

Mehedi,S.,Kuddus,M.A.,\&Maniruzzaman,M.(2017).THE IDENTIFICATION OF BANKERS'PERCEPTION TOWARD INDICATORS FOR THE ADOPTION OF GREEN BANKING IN BANGLADESHI SCHEDULED COMMERCIAL BANKS. Journal of Internet Banking and Commerce, 22(2).

Muth, M., \& Donaldson, L. (1998). Stewardship theory and board structure: A contingency approach. Corporate Governance: An International Review, 6(1), 5-28.

Nicholson, G. J., \& Kiel, G. C. (2007). Can directors impact performance? A case-based test of three theories of corporate governance. Corporate Governance: An International Review, 15(4), 585-608.

Park, Y.W.,\&Shin,H.H.(2004).Board composition and earnings management in Canada. Journal of Corporate Finance, 10(3), 431-457.

Pearce, J. A., \& Zahra, S. A. (1991). The relative power of CEOs and boards of directors: Associations with corporate performance. Strategic management journal, 12(2), 135-153.

Prevost, A. K., Rao, R. P., \& Hossain, M. (2002). Determinants of board composition in New Zealand: a simultaneous equations approach. Journal of empirical finance, 9(4), 373-397.

Rashid, A., De Zoysa, A., Lodh, S., \&Rudkin, K. (2010). Board composition and firm performance: Evidence from Bangladesh. Australasian Accounting, Business and Finance Journal, 4(1), 76-95.

Rashid, A. (2011).Corporate governance in Bangladesh: A quest for the accountability or legitimacy crisis?.Research in Accounting in Emerging Economies, 11, 1-34.

Rashid, A., De Zoysa, A., Lodh, S., \&Rudkin, K. (2012). Reply to" Response: Board composition and firm performance: Evidence from Bangladesh-a sceptical view".

Rashid, A. (2013). CEO duality and agency cost: evidence from Bangladesh. Journal of Management \& Governance, 17(4), 989-1008.

Rechner, P. L., \& Dalton, D. R. (1986). Board composition and shareholder wealth: An empirical assessment. International Journal of Management, 3(2), 86-92.

Ronner, A. E. (1998). Toward an integrative explanation of corporate financial performance: Kluwer Academic Publishers, 1996.

Scott, W. R. (2005). Institutional theory: Contributing to a theoretical research program. Great minds in management: The process of theory development, 37(2005), 460-484.

Shleifer, A., \&Vishny, R. W. (1997). A survey of corporate governance. The journal of finance, 52(2), 737-783.

Singh, M.,\&Davidson,W.N.,III(2003).Agencycost,ownershipstructureandcorporategovernancemechanisms. Journal of Banking and Finance, 27(5), 793-816.

Solomon, J. (2007). Corporate governance and accountability. John Wiley \& Sons.

Yermack, D. (1996). Higher market valuation of companies with a small board of directors. Journal of financial economics, 40(2), 185-211.

Zahra, S. A., \& Pearce, J. A. (1989). Boards of directors and corporate financial performance: A review and integrative model. Journal of management, 15(2), 291-334. 